cemoti $\begin{aligned} & \text { Cahiers d'études sur la Méditerranée } \\ & \text { orientale et le monde turco-iranien }\end{aligned}$

33 | 2002

Musulmans d'Europe

\title{
La jeunesse musulmane européenne : vers une identité commune?
}

Stéphane LATHION

\section{(2) OpenEdition}

Édition électronique

URL : http://journals.openedition.org/cemoti/726

DOI : $10.4000 /$ cemoti.726

ISSN : $1777-5396$

Éditeur

AFEMOTI

\section{Édition imprimée}

Date de publication : 1 janvier 2002

Pagination :

109-125

ISSN : 0764-9878

Référence électronique

Stéphane LATHION, « La jeunesse musulmane européenne : vers une identité commune? », Cahiers d'études sur la Méditerranée orientale et le monde turco-iranien [En ligne], 33 | 2002, mis en ligne le 01 avril 2004, consulté le 08 septembre 2020. URL : http://journals.openedition.org/cemoti/726 ; DOI https://doi.org/10.4000/cemoti.726

Ce document a été généré automatiquement le 8 septembre 2020

Tous droits réservés 


\title{
La jeunesse musulmane européenne : vers une identité commune?
}

\author{
Stéphane LATHION
}

\section{RÉSUMÉS}

L'objet de l'étude vise à faire le constat de l'existence de musulmans auteurs d'un discours unificateur. Malgré des origines, des parcours différents et des contextes distincts, la possibilité d'une rencontre des musulmans autour d'un discours qui se réfère aux sources (Coran et Tradition du Prophète) mais qui tient compte du contexte européen afin d'élaborer une jurisprudence islamique (figh) adaptée à la société dans laquelle ils vivent. Nous voulons mettre en évidence, à l'aide d'exemples et de propositions concrètes, l'existence d'une réelle volonté des musulmans européens engagés de participer au développement de la société à laquelle ils appartiennent. Ce que nous souhaitons mettre en évidence, enfin, c'est le fait que, contrairement à l'idée souvent avancée, l'islam peut être un facteur d'intégration pour la jeunesse musulmane née et élevée en Europe. Ces musulmans que nous appelons «engagés " revendiquent, tout en respectant le cadre légal européen, leur identité islamique. Ils se considèrent à la fois musulmans et Français, Anglais ou Suisses sans qu'il y ait, à leurs yeux, incompatibilité ou conflits d'intérêts. Loin des problèmes d'appartenances et de l'absence de points de repères (lieux ou personnes) dont ont pu souffrir leurs aînés dans les années quatre-vingt, les jeunes musulmans européens désireux de vivre leur foi en Europe bénéficient de possibilités d'encadrement autrement plus diversifiées. Ces jeunes responsables associatifs sont le moteur d'une transformation du paysage musulman européen : l'expérience personnelle, le contexte social ont interrogé la foi avant d'être le moteur d'un engagement, d'une réflexion et de l'élaboration d'un discours. 